\title{
FUEL STATION VALUATION UNDER POLISH AND RICS STANDARDS
}

\author{
Mirosława Czaplińska, M.Sc. \\ Kancelaria Majątkowa POMERANIA \\ e-mail:biuro@kmpomerania.com
}

\author{
Małgorzata Rymarzak, PhD \\ Faculty of Management \\ University of Gdansk \\ e-mail:malgorzata.rymarzak@ug.edu.pl \\ Dariusz Trojanowski, PhD \\ Faculty of Management \\ University of Gdańsk \\ e-mail:dariusz.trojanowski@ug.edu.pl
}

\begin{abstract}
In the last few years, there has been a visible change in the structure of the fuel station market in both Poland and the United Kingdom. The changes taking place both in the fuel station market structure and the management forms of fuel stations, along with the increasing significance of convenience goods sales, result in the necessity of verifying the existing Polish valuation standards of the income approach. Moreover, there is an urgent need to develop specific fuel station valuation guidelines. Fuel station valuation requires both the specific approach and profits method adjustment to be able to account for the specificity of the valuation. The universal character of property valuation in Poland cannot result in ignoring the specificity of fuel station valuation and the market where it operates. Property valuers undertaking valuations of this type of facilities must be familiar with the rules operating on the fuel station market.

This paper focuses on the comparison analysis of the fuel station market structure in Poland and the United Kingdom along with the specificity of the way fuel stations operate. Its emphasis is on the comparison analysis of fuel station valuation methods under Polish and RICS standards in order to show their similarities and differences. The aim of the paper is to present the methods of fuel station valuation in Poland and the United Kingdom, though mainly to show the areas of changes in the Polish valuation standards with regards to the profits method under the income approach that would take into account the specificity of fuel stations and their market.
\end{abstract}

Key words: property, fuel station, valuation, profits method.

JEL Classification: $D 46$.

Citation: Czaplińska M., Rymarzak M., Trojanowski D., 2017, Fuel Station Valuation Under the Polish and RICS Standards, Real Estate Management and Valuation, vol. 25, no. 2, pp. 20-32.

DOI: 10.1515/remav-2017-0010

\section{Introduction}

Property valuation that makes use of the profits method requires professional knowledge of the trade which it is connected with. The specificity of properties generating income makes universal methods of valuation insufficient; therefore, it is necessary to adjust the valuation methods and techniques to 
the operational model of such specialized properties. According to the authors of this article, fuel stations constitute such types of properties. From a scientific point of view, the methods and practices used for property valuation in different countries seem extremely interesting. This article aims to present and compare the valuation methods of fuel stations in Poland and the United Kingdom. These countries have been selected because the principles used in the UK are based on the RICS standards, which are international and used in many European countries.

The research was carried out in 2015 on the basis of the authors' own experience in fuel station valuation, as well as a study of literature, and analysis of binding laws, professional standards and practical analyses. The paper summarizes knowledge on the topic, provides the first systematic review of the available literature, and presents the similarities and differences of fuel station valuation in Poland and the UK. Most papers focus on either the Polish or British context. A need for a detailed comparison of the Polish and British markets along with the property valuation solutions used in these countries was identified. The present review fills this gap in literature, provides some managerial implications, and identifies areas for more detailed research on fuel station valuation.

It has to be emphasized that the fuel station market is changing and adjusting to the needs of its participants (including the customers). This means that the models of fuel station management valid today may become useless in the future, and this will lead to changes in fuel valuation methods. If so, further studies into the subject area will be required.

This paper can be a source of guidelines for property valuers from other countries who evaluate fuel stations using the British standards and come across similar problems as property valuers in Poland.

\section{Fuel stations as a valuation concern}

The role and features of fuel stations have changed enormously over the last few decades. Initially, fuel stations were perceived as a site where solely fuel was sold for road vehicles. As time went on, however, other goods, such as confectionery and drinks, became available at fuel stations. Hence, the offer of non-fuel items expanded from the payment zone to the entire area of the outlet. "In the late 1990s, when store sales generated a higher margin than fuel sales, the still-called "petrol stations" became points of sale addressing the needs of people on-the-move. Offers targeting drivers' comfort became a major profit lever for fuel retailers" (AZIMONT, ARAUJO 2010).

Nowadays, the notion of a fuel station may be understood as the land used to sell motor vehicle fuel. It may also include: "selling of motor vehicle accessories or parts; selling of food, drinks and other convenience goods; hiring of trailers; servicing or washing of motor vehicles; and installing of motor vehicle accessories or parts" (VICTORIAN GOVERNMENT 2011).

On many occasions, fuel station owners, constantly expanding their non-fuel offer and looking for new areas to generate income, have decided to extend the fuel station building, at the same time increasing their demand for land. The property valuer's job while evaluating fuel stations is, among others, to take into consideration this kind of tendency and to verify the potential extension of the facility.

Under the Polish law, the sale of fuel is carried out mainly at liquid fuel stations or self-contained LPG filling stations. According to the Regulation of the Minister of Economy, liquid fuel stations are defined as follows: "These are structures that may comprise: buildings, underground liquid fuel storage tanks, above or underground LPG tanks, liquid-fuel and LPG measuring systems, engineering installations along with liquid fuel and LPG storage and loading equipment, power supply and water supply, and sewage systems, drives and shelters, and other service-oriented devices and auxiliary and technical rooms" (REGULATION 2005).

Apart from the classification resulting from the legislation, one can find other classifications of fuel stations in literature, like the ones based on criteria such as: localization, customer dedicated offer, ownership, or the fuel management system. However, from the perspective of this paper, the following criterion of fuel station division (ownership) seems to be the most significant, nota bene it is the one most commonly used in economic practice. In general, there are three types of fuel station owners. These comprise the following (OECD 2013; Petrol Retailers AssOciation 2015; EnERGY INSTITUTE 2014; KWONG KIAT 2014):

- Companies/vertically integrated oil companies (TAYLOR 2000; OECD 2013): this refers to fuel stations owned or leased by the supplying oil company, whose name appears on the brand sign 
(such as BP owning and operating a fuel station under its own brand). Such a fuel station can be operated by the company's own retail subsidiary or leased/licensed to another individual or group.

- Dealers/independent retailers: this refers to fuel stations owned and operated by an individual or group that is not part of an oil company or a hypermarket (HAYWARD 2008).

- Hypermarkets/supermarkets: this refers to fuel stations owned and operated by a hypermarket/supermarket and retailing their own brand fuel. Hypermarkets' service stations are usually located near big population centers.

The classification of fuel stations according to the management system, that is, the relations between the fuel station owner and operator, constitutes a separate issue. This classification must be taken into account from the perspective of income and costs generated by the facility, which are indispensable to calculating the value of the fuel station. Taking this criterion into account, fuel stations can be classified as follows (CZAPLIŃSKA and TROJANOWSKI 2012; OECD 2013; KWONG KIAT 2014):

- Company Owned Company Operated (COCO) - fuel stations whose owner is, at the same time, its operator, that is, the fuel and non-fuel commodity vendor (this type is used not only for company stations but also for independent ones individually operated by entrepreneurs). In the UK, oil company fuel stations are very well located; therefore, they have a high level of fuel sales volume. However, the acquisition of the fuel stations with high trade potential by oil companies is conditioned by both market factors and the company budget as well. Moreover, the acquisition in question is usually not investment-oriented (Hayward, 2008, 386). Oil companies operate on the basis of budget parameters, the availability of funds and market demand, which, when combined, form the grounds for making offers of fuel station acquisition by the companies. Therefore, the valuers who analyze the concluded transactions of fuel stations must be careful as, in some cases, the oil companies pay a high price for the localization not because of investment purposes but because of the high fuel sales volume potential and the basic target which is building an efficient distribution channel. Oil companies building a retail distribution channel obtain not only refining and wholesale profit margins but also a retail profit margin that constitutes a very important factor in the calculation of trade profitability as seen from a broader perspective.

- Company Owned Dealer Operated (CODO) - fuel stations whose owner is not at the same time their operator, that is, the vendor of the fuel and non-fuel commodities. The operator sells the fuel that is the property of the station owner (mainly the oil company) on the oil company's behalf and to its benefit. In Poland, the introduction of this type of fuel station onto the market aimed at moving the risk associated with human resource management onto the dealer (Polish: ajent) and at increasing the efficiency of fuel station operating costs management (CZAPLIŃSKA and TROJANOWSKI 2012). The owner, on the basis of the agreement, transfers the station along with all the facilities and equipment to the dealer, and the dealer operates the fuel station. Contrary to the British solutions, there is no obligation to the invest dealer's own financial resources in the working capital.

- Dealer Owned Dealer Operated (DODO) - fuel stations constituting the property of private operators and operated directly by them. These stations often operate under the so-called patronage agreement. The oil company enables the station owner to sell fuel under their own brand, providing the station design in return for concluding an agreement of fuel supply from the oil company in question (usually an exclusive agreement). In Poland, oil companies are withdrawing this system and substituting it with DOFO solutions, which results in reducing the number of the independent fuel stations on the market.

- Dealer Owned Franchise Operated (DOFO) - fuel stations that constitute the property of the private operator and are operated by an independent operator under a franchise agreement, which sets a specific level of standards functioning on the oil company market. The franchisees run the station on their own behalf and to their own benefit. These are the most common types of stations found in Poland due to the current restructuration. Usually, the oil companies incur the costs of station modernization and, in return, obtain a franchise fees. The franchisee is the owner of the property and the station operator at the same time. In Poland, some Shell, BP, LOTOS, and Orlen fuel stations operate under the DOFO system. 


\section{Fuel station market in Poland and the UK - comparison analysis}

Over the last ten years, the number of fuel stations both on the Polish and British market has been declining (Figure 1).

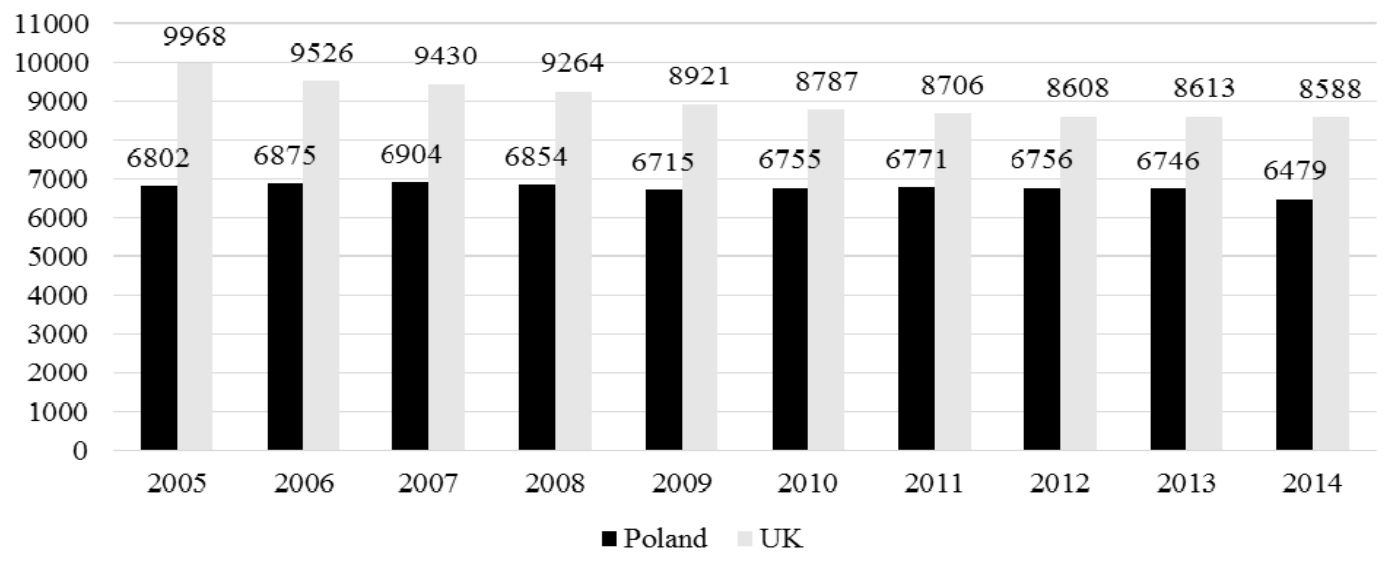

Fig. 1. The number of fuel stations in Poland and the UK in 2005-2014. Source: authors' own research based on POPiHN 2014; POPiHN 2015; Statista 2015.

In Poland, the total went down from over 6,800 in 2005 to 6,479 at the end of 2014 (nearly a 5\% decrease), while in the UK, the number of fuel stations declined from more than 9,900 in 2005 to less than 8,600 (nearly a $14 \%$ decrease). The main reasons for this situation are the increasing costs of compliance with environmental regulations and strong competition among fuel retailers (UK PIA 2015). Moreover, the fuel companies in Poland have been carrying out numerous restructuring activities (POPIHN 2014).

Apart from the similar trends present on both markets over the last few years, a detailed analysis shows that the markets differ from each other, among others, with respect to the ownership structure. While in Poland, in 2014, oil company stations were dominant (55.69\%), in the UK, at the same time, independent retailers constituted the biggest group - 62.62\% (Table 1 ).

Table 1

Fuel station share in market according to ownership structure in Poland and UK in the years 2005$2014(\%)$

\begin{tabular}{lcccccccccc}
\hline Specification & 2005 & 2006 & 2007 & 2008 & 2009 & 2010 & 2011 & 2012 & 2013 & 2014 \\
\hline Poland & & & & & & & & & & \\
\hline Companies & 47.60 & 48.39 & 49.23 & 49.33 & 50.41 & 50.17 & 51.94 & 53.23 & 53.96 & 55.69 \\
\hline Dealers & 51.46 & 50.18 & 49.25 & 48.88 & 47.65 & 47.67 & 45.78 & 44.40 & 43.58 & 41.67 \\
\hline Hypermarkets & 0.94 & 1.43 & 1.52 & 1.79 & 1.94 & 2.16 & 2.27 & 2.37 & 2.46 & 2.64 \\
\hline UK & & & & & & & & & & \\
\hline Companies & 24.22 & 23.34 & 23.23 & 23.64 & 24.99 & 25.22 & 25.38 & 25.29 & 22.37 & 21.29 \\
\hline Dealers & 64.25 & 64.34 & 64.11 & 63.35 & 61.34 & 60.45 & 60.06 & 59.54 & 61.99 & 62.62 \\
\hline Hypermarkets & 11.54 & 12.32 & 12.65 & 13.01 & 13.68 & 14.33 & 14.55 & 15.17 & 15.64 & 16.09 \\
\hline
\end{tabular}

Source: authors' own research based on POPiHN 2014; POPiHN 2015; Statistica 2015.

In Poland, in comparison with the year 2005, the share of oil company stations, especially of foreign ones, increased by 8.09 percentage point. Hypermarkets also increased their share (by 1.7 percentage point). The number of stations operating at shopping centres increased from 64 in 2005 to 171 at the end of 2014. The share of independent retailer stations, on the other hand, declined by 9.79 percentage points.

Considerable variations in the rate of decline (or growth) between different types of fuel station owners were, among others, the result of the implementation of new technical requirements for the stations. These resulted in the closure of a number of facilities that were not adequately modernized. (POPiHN 2014). 
Moreover, the profitability of many of the stations declined due to the new traffic distribution in Poland (the construction of motorways). Since 2009, a new fuel market section of motorway fuel stations has been developing. The number of these stations has increased threefold in the last six years, i.e., from 21 to 71 .

The fuel stations that continued their trade-related activity survived on the market thanks to the sales of non-fuel goods and services. For yet another consecutive year, the margin earned from selling fuel was insufficient to cover the costs of fuel station maintenance (POPiHN 2014).

In the UK, the only section of the petrol station market that has been growing since 2005 is large hypermarket sites. Their share in 2014 in comparison with 2005 increased by 4.55 percentage points and, today, has reached over $16 \%$. The growth in hypermarket-owned fuel stations was broadly in line with the growth of hypermarkets in the grocery retailing business (DELOITTE 2012). In 2014, hypermarkets, despite owning a comparatively small number of fuel stations $(1,410$ out of 8,588 fuel stations in the UK), sold $44 \%$ of all petrol and $42 \%$ of diesel (UK PIA 2015).

The share of oil company fuel stations declined (by 2.93 percentage points), as did the share of those owned by independent retailers (by 1.63 percentage points). Independent dealers continue to face pressure on their business models. This is primarily due to competition from hypermarkets and the growing importance of non-fuel sales. The average independent site's throughput in 2014 was just over 2 million litres, whilst supermarket sites average around 11 million litres per year (UK PIA 2015). Smaller independent retailers have typically not been able to offer such a competitive package of fuel and retail products at their sites, which has led to the closure of a large number of smaller sites (DELOITTE 2012).

In the UK, like in Poland, the fuel station operators have appreciated the importance of non-fuel commodity sales. Within the dealer sector, $90 \%$ of sites had a shop and $24 \%$ of the sites $(1,173)$ had a convenience store in 2014 (Forecourt Trader, 2014, 31). The participation of the customers buying only fuel has been declining from year to year. In 2011, it was 52\%, while in 2014, it was about $37 \%$. The number of customers without cars has also been growing. In 2014, it reached 13\% (PETROL RETAILERS ASSOCIATION 2015).

\section{The principles of fuel station valuation in Poland}

In Poland, one can distinguish the following approaches to property valuation: the comparison, income, cost and mixed approach. The comparison approach comprises a method that compares pairs of properties, the method of average price adjustment and market statistical analysis. In the income approach, we deal with the investment method and profits method. The cost method comprises substitution and replacement cost methods. The mixed approach includes the residual method and closing cost method.

While assessing the market value of a property, one has to take market indicators into consideration. The purchasers and vendors of commercial properties are concerned with the income which the facilities generate and the risk related to an investment in a given market section. Therefore, the factor that determines the value of a commercial property, including fuel stations, is the income assigned to it. In Poland, in most cases, the profits method is the most appropriate of the available methods (CZAPLIŃSKA and TROJANOWSKI 2012).

Theoretical principles of applying the profits method have been described in subject-related literature (DYDENKO 2014). However, the valuation procedures described there are universal and, in fact, constitute a general formula that should be adapted to the specificity of the assessed property. The procedures described in professional standards need to be specified (POWSZECHNE KRAJOWE ZASADY WYCENY 2014):

- The User's Turnover (UT) determined on the basis of the trade-related activity, carried out at the property.

- User's Gross Income (UGI) calculated as the difference between the User's Turnover and the User's Operating Costs (KOU).

- User's Net Operating Income (UNOI) calculated as the difference between the User's Gross Income (UGI) and the Operating Expenses (OE).

- Net Operating Income (NOI) of the property owner calculated as the property owner's participation in the User's Net Operating Income (UNOI). The amount of income is determined on the basis of market data or in any other reasonable way. 
Property valuation that makes use of the profits method requires the separation of the income assigned solely to the property owner from the income generated by the trade-related activity carried out on the property. This results from the fact that the property value is assessed solely on the income assigned to the property owner (TROJANOWSKI 2010). In the profits method, one can distinguish two techniques: capitalization and discounted cash flow (TROJANEK 2014).

In addition to the above analysis, one can think of cases where it would be possible to apply the investment method in fuel station valuation, that is, the method that uses rent to assess the value of the property. However, the objectivization of the amount of flat rent in comparison to other similar properties constitutes a problematic issue. In the case of fuel stations, it is difficult to define a proper comparison unit in which rent may be expressed and, later on, used to compare two different lease agreements. Units such as area, building floorage or the size of fuel tanks are inappropriate, as all of them do not cover essential aspects of fuel station profitability and may ultimately lead to incorrect conclusions. The application of percentage rent, whose value depends on e.g. cash receipts, seems to be the most appropriate here. Rent defined in this way is closely related to station profitability and takes into account its specificity. However, the number of lease agreements defining the rent in percentage is limited and, therefore, the objectivization of rent value is difficult to achieve.

Summing up, the authors of this article believe that the profits method is the most appropriate tool for fuel station valuation, above all, because it gives the possibility of taking into consideration the basic factor determining its value, that is, the generated income. If the fuel station was operating under a permanent lease agreement (that is with a fixed date), it would be necessary to take into consideration the impact of this agreement on the property value. In this case, it would be more appropriate to apply the investment method to assess the value of the fuel station during the term of the agreement and the profits method to assess the residual value.

\section{The principles of fuel station valuation in the UK}

In the UK, the standards published by the Royal Institution of Chartered Surveyors (RICS), entitled RICS Valuation - Professional Standards (the "Red Book"), are the most important in property valuation. These standards establish the rules of conduct and recommendations for property valuers. Their aim is to ensure that persons or entities ordering a valuation will have a guarantee that the valuations carried out by the valuers who are the members of the RICS will be done according to the highest professional standards and fulfil the requirements of independence and objectivity, and will be in line with the internationally accepted standards published by the International Valuation Standards Council (IVSC) (RICS 2014). These standards form a framework for the best professional practices of carrying out valuations and providing them to customers who order them for various purposes. However, these standards do not comprise the guidelines of how to assess a given asset component in a specific case.

RICS publishes 3 types of documents of a different hierarchy of importance (RICS 2014):

- RICS Professional Standards (PS) - mandatory - they define the parameters for compliance with the Red Book, including the adoption of the International Valuation Standards, set out the associated RICS regulatory requirements, and clarify the detailed application of the RICS Rules of Conduct when members are undertaking valuation work. They comprise: PS 1 - Compliance with Standards and Practice Statements, where a written valuation is provided, and PS 2 Ethics, Competency, Objectivity and Disclosures.

- RICS Global Valuation Practice Statements (VPS) - mandatory - they contain specific, mandatory (unless otherwise stated) requirements and related implementation guidance in relation to the process of providing a valuation that is IVS-compliant.

- RICS Global Valuation Practice Guidance - Applications (VPGA) - advisory - they provide further implementation guidance in the specific instances listed. They embody "Best Practice" that is procedures that, in the opinion of RICS, meet a high standard of professional competence. They comprise, among other things, VPGA 4 - Valuation of Individual TradeRelated P -properties.

Other RICS publications that may have relevance to valuation may also be obtained from the RICS website (www.rics.org/guidance). They include practice statements, guidance notes and valuation information papers.

In British literature (SCARRETT 2008; ISAAC and O'LEARY 2012), there are five basic methods of 
valuation: the comparison method of valuation, the residual method of valuation, the investment method of valuation, the profits method of valuation and the contractor's method of valuation. The profits method is considered the most appropriate one in fuel station valuation because of the specificity of this type of property, where it is impossible to use the comparison method (SCARRETT 2008; ISAAC and O'LEARY 2012). The financial results of the business entity and various trade information that enable the determination of the net and gross profit constitute the grounds for the profits method of valuation (SCARRETT 2008). Next, it is necessary to make deductions deriving from the interest on the capital that the user involved in the trade activity carried out on the property and his/her remuneration for its management. The amount remaining after the adjustments is defined as a "divisible balance" and constitutes the value to be respectively divided between the user and the property owner (SCARRETT 2008; BAUM et al. 2006). The "divisible balance" is very often divided equally between the parties, but in fact, it should reflect the participation of each party in the success of the trade-related activity on the property.

Fuel stations in the UK are classified as a group of trade-related properties and their valuation is discussed in the valuation standards of property valuers in the so-called "Red Book" in the part entitled "VPGA 4: Valuation of individual trade-related properties". The main characteristic of a property with trading potential is that it is designed for a specific usage and, therefore, lacks flexibility (RICS 2014). This means that the value of the property is closely related to the income that the owner may generate from this specific usage. Therefore, the value reflects the trading potential of the property. Valuers who prepare the valuation of the property with trading potential must specialize in a given property market section because knowledge of the operating aspects of these properties and the market section where they operate is fundamental for understanding the market transactions and the market analysis being carried out. The level of the estimated income is calculated assuming that market participants (REOs - Reasonably Efficient Operators) are effective and competent operators of property trade and, therefore, the valuer assesses the trade potential on the basis of market analysis. The actual level of the income generated by the user (assessed on the basis of accounting data) is only of an informative nature and may be verified by deducting the part of the income associated with the so-called personal goodwill. The period of analysis of accounting data should comprise 3 years (ISAAC and O'LEARY 2012; SCARRETT 2008). The actual trading performance currently achieved by the fuel station should be compared to similar trade-related properties with the same trade potential and a similar manner of operation.

Fuel stations, just like other trade-related properties, such as: hotels, bars or restaurants, are evaluated according to a procedure comprising the following steps (RICS 2014):

Step 1: An assessment of FMT (Fair Maintainable Turnover) that could be generated at the property by a REO. FMT is the level of trade that REO may expect to achieve assuming that the property is properly equipped, repaired, maintained and decorated. FMT.

Step 2: Where appropriate, an assessment is made of the potential gross profit, resulting from the

Step 3: An assessment of the FMOP (Fair Maintainable Operating Profit) defined as the level of profit stated prior to depreciation and financial costs that the reasonably efficient operator (REO) could expect. The depreciation and financial costs relate to the asset itself. FMOP is calculated on the basis of fair maintainable turnover (FMT). It should reflect all costs and outgoings of the REO and an appropriate annual allowance for periodic expenditure, such as decoration, refurbishment and the renewal of trade inventory.

Step 4:

a) To assess the Market Value of the property, the FMOP is capitalised at an appropriate rate of return reflecting the risk and rewards of the property and its trading potential. Evidence of relevant comparable market transactions should be analysed and applied.

b) In assessing Market Value, the valuer may decide that an incoming new operator would expect to improve the trading potential by undertaking alterations or improvements. This will be implicit within the valuer's estimate of FMT at step 1. In such instances, an appropriate allowance will be made from the figure resulting from step 4 to reflect the costs of completing the alterations or improvements and the delay in achieving FMT. Similarly, if the property is in need of repair and/or decoration to enable the REO to achieve the FMT, then an appropriate allowance should be made from the figure resulting from step 4(a) to reflect the cost of such repairs and decorations. 
c) To assess the market rent for a new letting, the rent payable on a rent review or the reasonableness of the actual rent passing (particularly when preparing an investment valuation), an allowance should be made from the FMOP to reflect a return on the tenant's capital invested in the operational entity - for example, the cost of trade inventory, stock and working capital. The resultant sum is referred to as the divisible balance. This is apportioned between the landlord and tenant having regard to the respective risks and rewards, with the landlord's proportion representing the annual rent.

The RICS, seeing the difficulty in the fuel station valuation, prepared an additional Information Paper document called "Capital and Rental Valuation of Fuel Stations". It is devoted solely to fuel station valuation. This document comprises the guidelines that should be taken into consideration by valuers who undertake such valuations. Within it, one can find information on fuel station types, formal and legal documents essential for the operation fuel stations and which the station operator should have and make available during the valuation process, and guidelines for market analysis, station market value assessment and market rent assessment.

The fuel station valuation according to the British standards assumes that trade will continue and that the facilities of this type are valued along with the equipment necessary to run the trade-related activity (RICS 2014).

The market decides about the very value of the fuel station. The valuer assessing the trade-related property has to understand the trade aspects of this property to be able to: properly understand and compare the physical features of the property, such as the localization, size, functionality, and additional services; to analyze the current trading results; to assess the trading conditions and their impact on the financial result (especially if the trade is linked to the fuel supply or any other non-fuel commodities agreements); to properly analyze the profit margin - it has to be assessed and analyzed if the profit margins on fuel or other commodities are stable; and to assess the trade-related potential, profitability and market demand.

While valuing the fuel station, the valuer has to take into consideration all factors contributing to the sales volume of fuel and other commodities. These factors may comprise changes to the road structure, traffic density variations, and the possibilities of the construction of new fuel stations or the closing of existing ones whose sales volume may be transferred onto the valuation of the fuel station under consideration (HAYWARD 2008). Market data on the sales of other stations located in the area concerned by the valuation will have a significant impact on the valuation, but they are difficult to obtain and the valuer will have to carry out his own research with respect to the selling of these stations. The sales volume may differ a great deal due to, e.g. the accessibility, visibility, and lay-out of the facility, as well as the operator's standards and pricing policy. The British standards of valuation including the RICS Information Paper "Capital and Rental Valuation of Fuel Stations" not only describe fuel station market value assessment but also focus on market rent assessment and property value assessment for investment purposes. To assess the market rent for a new lease, it is, first of all, necessary to analyze all the proposed assumptions and conditions of the lease agreement including the leased property, the period of leasing, costs that the tenant must incur to be able to operate the station, e.g. equipment costs, and issues such as to who will pay for repairs and modernisation. The assessment of the income generated by the property is analogical to the assessment of the market value, however, in step 3, the appropriate allowance must be made from the FMOP to reflect the return on the capital that the tenant invested in the operational entity - for example, the cost of commodities, trade stock and working capital. The amount (the difference received from this calculation) is defined as the divisible balance. This is apportioned between the landlord and tenant having regard to the respective risks and rewards, with the landlord's proportion representing the annual rent.

\section{Comparison analysis of the valuation principles}

The comparison analysis of the valuation principles under the profits method following Polish and British standards is presented in Table 2 and 3.

Table 2 Comparison analysis of calculation of income in the profits method under Polish and British standards 
The User's Turnover (UT) determined on the basis of the operating activities carried out at the property.

The User's Gross Income (UGI) calculated as the difference between the User's Turnover and the User's

Operating Costs (UOC). The user's operating costs comprise all expenditures related to the trade-related activity and which condition the expected turnover. In particular, they include the costs of purchasing commodities, materials and services, staff remuneration along with all extra expenses such as, e.g., health insurance or social security, the costs of

fixed assets and the equipment of replacement, advertising costs and so on. The user's operating costs do not comprise depreciation, finance costs (along with bank loan services) and the income tax paid by the user.

The User's Net Operating Income (UNOI) calculated as the difference between the User's Gross Income (UGI) and Operating Costs (OC).
The assessment of FMT (Fair Maintainable Turnover) that could be generated at the property by an REO.

Potential gross profit resulting from the FMT (if necessary).
The assessment of the FMOP (Fair Maintainable Operating Profit) defined as the profit level prior to depreciation and finance costs related to the asset itself

(and rent if leasehold) that a reasonably efficient operator (REO) would expect to derive from the FMT based on an assessment of the market's perception of the potential earnings of the property. It should reflect all costs and outgoings of the REO and an appropriate annual allowance for periodic expenditure, such as decoration, refurbishment and renewal of the trade inventory.

The Property owner's Net Operating Income (NOI) calculated as the property owner's participation in the User's Net Operating Income (UNOI). The level of this income is determined on the basis of market data or in any other reasonable way.

Source: author's own research on the basis of: POWSZECHNE KRAJOWE ZASADY WYCENY 2014; RICS 2014.

According to Polish standards, market value is assessed by the capitalization of the user's net operating income according to the appropriate rate of return. In the case of the British standard, market value is assessed by the capitalization of the FMOP according to the appropriate rate of return. In both countries, it is possible to use a capitalization technique or a discounted cash flow technique.

Comparison analysis of the remaining valuation aspects under Polish and British standards

\begin{tabular}{ccc}
$\begin{array}{c}\text { Comparison } \\
\text { Category }\end{array}$ & Polish Standards & British Standards \\
\hline $\begin{array}{c}\text { Income } \\
\text { calculation } \\
\text { base }\end{array}$ & $\begin{array}{c}\text { The base of the income valuation is derived } \\
\text { from the part of the income that is generated by } \\
\text { the trade-related activity carried out at the } \\
\text { property and which is closely-related to the } \\
\text { specificity of the property. It is a counterpart of } \\
\text { rent. }\end{array}$ & $\begin{array}{c}\text { The Fair Maintainable Turnover - the level of } \\
\text { trade the REO may expect on the assumption } \\
\text { there is proper equipment, repairs, } \\
\text { maintenance, fixtures and fittings. The FMT is } \\
\text { later adjusted by the operating costs. }\end{array}$ \\
\hline $\begin{array}{c}\text { Definition of } \\
\text { the user }\end{array}$ & $\begin{array}{c}\text { There is an assumption that a typical, } \\
\text { moderately efficient operator generates the } \\
\text { income. }\end{array}$ & $\begin{array}{c}\text { There is an assumption that the reasonably } \\
\text { efficient operator (REO) generates the income. }\end{array}$ \\
\hline $\begin{array}{c}\text { Importance } \\
\text { of the value } \\
\text { of equipment } \\
\text { in valuation }\end{array}$ & $\begin{array}{c}\text { Properties, due to their complex physical and } \\
\text { economic structure, are treated as trade-related } \\
\text { properties comprising various assets which are } \\
\text { necessary to carry out the trade activity. Apart } \\
\text { from the property itself, these also comprise } \\
\text { movables (furniture, equipment and devices) } \\
\text { and intangible and legal assets, such as so- }\end{array}$ & $\begin{array}{c}\text { The rule is that the property is evaluated } \\
\text { along with all the equipment and devices. If } \\
\text { the valuation does not reflect the equipment, } \\
\text { this has to be marked in the report. During the } \\
\text { property valuation, it is important to check if } \\
\text { the all of the equipment belongs to the } \\
\text { property owner. If there are any equipment }\end{array}$ \\
\hline
\end{tabular}


called transferable goodwill which constitutes a component of intangible and legal assets, is related to the brand, reputation, customers' trust and so on, and which is transferred onto the purchaser in the case of the property being sold. The value assessed with the help of the profits method may also comprise - in addition to the properties - other components of the assets.

Information The source of information on the level of source used in valuation property income is market data and data from the assessed property. While calculating the property income, one has to take into consideration the achieved results of the trade carried out at the property and market data on the income of similar trade activities on the market.

Personal "Personal goodwill" that has an impact on the goodwill user's income, however is not linked with the property but with its operator, is not taken into consideration. By personal goodwill, we understood specific features of a given user that contribute to an income level that differs from the market ones.

Rate of capitalization

The property valuer, during the valuation, accepts the capitalization rate on the assumption that a commensuracy principle is applied to calculate the income generated by the property.

The recommended way of assessing the capitalization rate is to calculate it as a quotient of the net operating income expected to be obtained on the market, and the property market price. In particular, the accepted capitalization rate should relate to the difference in the risk level between the assessed property and the properties being subject to the analysis of capitalization rates. The main risk factors influencing the level of the capitalization rate are, among others, as follows: the localization, the state of repair, the utility standard, the worthiness of tenants, the lease agreement terms having an impact on the assessed property, the building size and its functions, and heritage conservation. The level of the capitalization rate accepted in the assessment should also reflect the risk regarding the income changeability of the assessed property.

Market $\quad$ A general requirement of market analysis
analysis

A general requirement of market analysis lease agreements or any other obligation agreements where the property owner is merely the user of the equipment, the report should reflect this situation.

The source of information on the level of income is market data and data obtained from the assessed property; however, they are of supportive nature only.
"Personal goodwill" is not taken into consideration in valuation.
The use of the appropriate rate of return (the FMOP is capitalized at an appropriate rate of return reflecting the risk and rewards of the property and its trading potential).
It is necessary to analyze the current competition and take into consideration future changes in the property surroundings as they may have a significant impact on the future income and the concerned valuation. It is necessary to analyze potential changes in the law (permits, licenses, technical requirements) and the development of new roads that may have a significant impact on changes in the income level. 


\begin{tabular}{cc}
\hline $\begin{array}{c}\text { Division of } \\
\text { market value } \\
\text { into the }\end{array}$ & $\begin{array}{c}\text { The value assessed using the profits method } \\
\text { may also comprise - besides the assets - other } \\
\text { property components. If it is necessary to assess }\end{array}$ \\
$\begin{array}{c}\text { values of } \\
\text { individual } \\
\text { property }\end{array}$ & $\begin{array}{c}\text { a separate value of the property, it may be } \\
\text { calculated from the difference between the } \\
\text { value assessed using the profits method and } \\
\text { the market value of other property } \\
\text { components. }\end{array}$
\end{tabular}

Source: author's own research on the basis of: POWSZECHNE KRAJOWE ZASADY WYCENY 2014; RICS 2014.

On the basis of the comparison shown above, one may conclude that many of the elements in the Polish and British profits methods are similar. The main differences are as follows:

- In Poland, there is a lack of specialist guidelines for fuel station valuation. In the UK, these guidelines are presented in the form of the RICS Information Paper "Capital and Rental Valuation of Fuel Stations" and emphasize the analysis of the fuel station market and its trade potential.

- According to the Polish valuation standards, in the situation when the property owner is not its user, the valuer, while calculating the income, takes into consideration the property owner's participation in the user's income; however, the aspect of income adjustment by the interest on the user's capital invested in the trade is not mentioned.

\section{Conclusions}

The fuel market in both the UK and Poland has been undergoing structural changes in many fields of trade-related activities. In both countries, one can observe a decline in the number of fuel stations; however, there is an increase in the number of hypermarket fuel stations and, in Poland, we can additionally see the development of the MSA fuel station network. In both countries, we have been dealing with a significant development in the sales of non-fuel commodities and trade-related services. The latter has led to the station layout extension - the owners extend and modernize the buildings and, consequently, need more land. In Poland, there are a few different fuel station operating models that have an impact on the fuel station income and costs. The valuation model should be chosen in line with them. All these changes and development tendencies should be analyzed by the valuer during the fuel station valuation process and taken into account while calculating the potential turnover.

The Polish standards created in the 90ties were based, to a great extent, on British standards. In the opinion of the authors, the valuers rendering fuel station valuation services, while calculating the net operating income (NOI), should not include the property owner's participation in the user's net operating income. This participation should be reflected only if this fuel station operating model was dominant on the Polish market. Taking into consideration the fact that the current models (besides the motorway fuel station section) differ a lot from the solutions operating in the UK, this "artificial" participation assessment carried out only to fulfil the procedure requirements should not take place. The property owner's net operating income should comprise all the trade-related costs, along with the costs of the station operation by the dealer (ajent), if there is one, and if the agreement with him/her is transferred onto the purchaser. At the same time, it must be emphasized that, in Polish standards, the capital invested in the trade by the user is not emphasized in any special way. In some cases of valuation with the use of the profits method, this issue should be dealt with. The authors' experience shows that the majority of fuel stations in Poland under the CODO system do not fulfill the requirement of the dealer's (ajent') significant capital involvement in the station equipment. The owner of the fuel station transfers the fuel station along with its equipment and devices to the dealer, provides the dealer's employees with company clothes, and carries out all the administrative and legal activities, such as checking the conformance of fuel flow meters, cleaning tank and oil product separators, and seeing to the station repairs and refurbishment, provided that this is not otherwise defined in the agreement with the dealer (ajent) (CZAPLIŃSKA and TROJANOWSKI 2012). Fuels and commodities in the shop are generally sold by the dealer (ajent) on behalf and to the benefit of the owner, and only a few selected non-fuel commodities may be sold on behalf and to the benefit of the dealer (ajent). 
The RICS Information Paper "Capital and Rental Valuation of Fuel Stations" presents fairly detailed guidelines for fuel station valuers, whereas the Polish standards describe the valuation method generally, without drawing any special attention to the individual aspects of fuel stations and their specificity. It is the authors' opinion that this area of concern should be specified, taking into account the current situation of this market section and solutions operating there, especially in the field of the manner in which fuel stations are operated.

The authors believe that the Polish valuation standards of the income approach making use of the profits method should clearly indicate the aspect of the potential involvement of the user's capital if the market practice in the analyzed market sector indicates such proceedings (e.g. the necessity of carrying out building visualization, conducting building finishing works, equipping or providing the necessary working capital). The Polish standards should reflect the cost of the capital employed by the user in the assessment of the user's net operating income, as trade-related properties would not be able to operate without it.

It is very difficult for the property valuer to separate the assessment of the business of a traderelated property from the assessment of the value of a property, not only when the property owner does not carry out trade-related activities at the property (the property in question is only one of the user's investment forms), but also in the case when the user directly takes on the additional business risk (namely, the user carries out trade-related activities at the property that he/she owns). Therefore, the valuation of the property with a trade-related potential should be based on appropriately assessed income and a capitalization rate that has been properly calculated on the basis of market data, and which has been assessed in line with the principle of commensuracy.

\section{References}

Azimont F., ARAujo L., 2010, The Making of a Petrol Station and the "On-the-move Consumer": Classification Devices and the Shaping of Markets, Industrial Marketing Management., No. 39, pp. 1010-1018.

BAum A., Nunnington N., MACKMIN D., 2006, The Income Approach to Property Valuation, EG Books, Abingdon.

CZAPLIŃSKA M., TROJANOWSKI D., 2012, Sposób zarządzania a specyfika wyceny stacji paliw (Impact of Management Approach on Specificity of Petrol Filling Station Evaluation) [in Polish], Studia i Materiały Towarzystwa Naukowego Nieruchomości, No. 20 (2), pp. 201-214.

DELOITTE 2012, Study of the UK petroleum retail market 2012, https://www.gov.uk/government/ uploads/system/uploads/attachment_data/file/69760/7322-study-of-the-uk-petroleum-retailmarket.pdf (accessed 15.04.2016).

DYDENKO J. (Eds.) 2014, Szacowanie nieruchomości rzeczoznawstwo majątkowe (Property Valuation) [in Polish], Wolters Kluwer Polska, Warszawa.

ENERGY INSTITUTE 2014, Retail Marketing Survey, https://www.energyinst.org/information-centre/eipublications/petroleum-review/retail-marketing-survey-2015 (accessed 15.04.2016)..

FORECOURT TRADER 2014, Fuel Market Review 2014, http://forecourttrader.co.uk/files/ Fuel_Market_Review/Fuel_Market_Review_2014.pdf (accessed 15.04.2016).

HAYWARD R. (Eds.) 2008, Valuation: Principles into Practice, EG Books, Abingdon.

IsAAC D., O'LEARY J., 2012, Property Valuation Principles, Palgrave Macmillan, New York.

KWONG KIAT T., 2014, Maintaining Cntrol over Industry Architecture. The Fuel Retailing Industry. A Doctoral Thesis, National University of Singapore, http://scholarbank.nus.edu.sg/ bitstream/handle/10635/

79487/TayKK.pdf?sequence=1 (accessed 15.04.2016).

OECD 2013, Policy Roundtables. Competition in Road Fuel, http:/ / www.oecd.org/competition/ CompetitionInRoadFuel.pdf (accessed 15.04.2016).

PETROL RETAILERS ASSOCIATION 2015, Market Review 2015, http://www.ukpra.co.uk/_assets/ PRA_MarketReview2015_C.pdf (accessed 15.04.2016).

POPIHN 2014, Annual Report. Oil Industry and Trade 2014, http:/ /www.popihn.pl/raporty2.php.

POPIHN 2015, Stacje paliw w Polsce 2008-2015 (Petrol stations in Poland 2008-2015) [in Polish], http:/ / www.popihn.pl/stacje_paliw.php?news_id=117 (accessed 15.04.2016).

POWSZECHNE KRAJOWE ZASADY WYCENY 2014. NI Zastosowanie podejścia dochodowego w wycenie nieruchomości (Applying the Income Approach in Real Estate Valuation) [in Polish], 
,http://pfsrm.pl/sites/default/files/NI\%20\%20Zastosowanie\%20podej\%C5\%9Bcia\%20dochodow ego \%20w\%20wycenie\%20nieruchomo\%C5\%9Bci\%20\%5BUchwa\%C5\%82a\%20RK\%20nr\%2027_08 \%20z\%2009.12.2008\%20r.\%2C\%20obowi\%C4\%85zuje\%20od\%2001.03.2009\%20r.\%2C\%20w.\%2008.0 8.2014\%5D.pdf (accessed 15.04.2016).

RICS 2014, Valuation Standards - Professional Standards Global, London.

Rozporządzenie Ministra Gospodarki z dnia 21 listopada 2005 . w sprawie warunków technicznych, jakim powinny odpowiadać bazy i stacje paliw płynnych, rurociągi przesyłowe dalekosiężne służące do transportu ropy naftowej i produktów naftowych i ich usytuowanie (Regulation of the Minister of Economy of 21 November 2005 on the technical conditions that have to be met by base stations and liquid fuel pipelines for far-reaching transportation of crude oil and petroleum products and their location, with subsequent amendments (Dz. U. nr 243, poz. 2063) (Journal of Laws, No. 243 Item 20163).

SCARRETT D., 2008, Property Valuation the Five Methods, Routledge, Abingdon.

STATISTA 2015, Total number of petrol station sites in the United Kingdom (UK) from 2000 to 2014, http://www.statista.com/statistics/312331/number-of-petrol-stations-in-the-united-kingdom$\mathrm{uk} /$ (accessed 15.04.2016).

TAYLOR B. A., 2000, Retail Characteristics and Ownership Structure, Small Business Economics, no. 14 (2), pp. 157-164.

TROJANEK, M., 2014, Podejście dochodowe w wycenie nieruchomości. Przykłady i zadania (Income Approach in the Valuation of the Property. Examples and Problems) [in Polish], Wydawnictwo Uniwersytetu Ekonomicznego w Poznaniu, Poznań.

TROJANOWSKI D., 2010, Praktyczne aspekty zastosowania metody zysków do wyceny hoteli na polskim rynku nieruchomości (Practical Problems of using Profit Method for Hotel Valuation on Polish Real Estate Market) [in Polish], In: Szczepaniak K. (Eds.), Nieruchomości - wycena, opłacalność i ryzyko (Real Estate Valuation, Profitability and Risk), Wydział Zarządzania Uniwersytetu Gdańskiego, Sopot.

UK PIA 2015, Statistical Review 2015, http://www.ukpia.com/docs/default-source/defaultdocument-library/ukpia-2015-statistical-review4f265c889f1367d7a07bff0000a71495.pdf?sfvrsn=0.

VICTORIAN GOVERNMENT 2011, Specialist Property Guidelines for Petrol Stations, http://www.dtpli.vic.gov.au/_data/assets/pdf_file/0005/218777/VGV_MGV_PetrolStations_A ugust-2011.pdf (accessed 15.04.2016). 